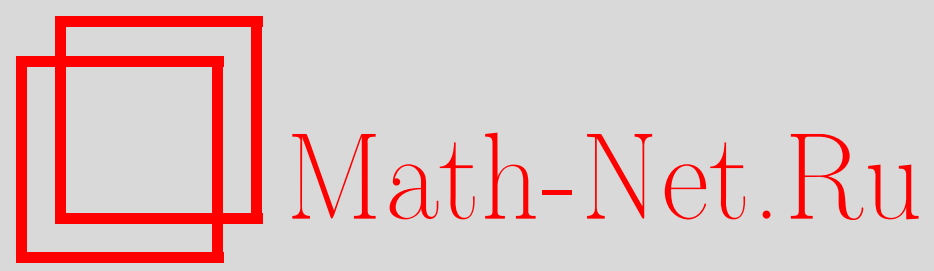

Вступительное слово вице-президента Академии криптографии Российской Федерации Владимира Николаевича Сачкова, Матем. вопр. криптогр., 2013, том 4, выпуск 2, 45-46

DOI: https://doi.org/10.4213/mvk81

Использование Общероссийского математического портала Math-Net.Ru подразумевает, что вы прочитали и согласны с пользовательским соглашением

http: //www. mathnet.ru/rus/agreement

Параметры загрузки :

IP : 52.23 .180 .231

26 апреля 2023 г., 12:29:13 


\title{
Вступительное слово вице-президента Академии криптографии Российской Федерации Владимира Николаевича Сачкова
}

\author{
Уважаемые участники мини-симпозиума \\ «Современные тенденции в криптографии» (CTCrypt-2012)!
}

В последние десятилетия в мире происходит интенсивное внедрение компьютерных технологий передачи и обработки информации во всех сфеpax человеческой деятельности (в английском языке существует специальный термин для обозначения этого явления - ubiquitous computing, в дословном переводе означающий «повсеместные вычисления»). В связи с этим возникают новые угрозы информационной безопасности, и требуется развивать методы синтеза и анализа механизмов защиты от данных угроз, в том числе, и даже в первую очередь, криптографических механизмов. В современных условиях использование криптографии вышло далеко за рамки защиты частной переписки, банковских транзакций и государственных секретов. Паспортно-визовые документы нового поколения, персональные данные и врачебная тайна, предоставление государственных услуг в электронном виде, электронное голосование и облачные вычисления - вот далеко не полный перечень современных сфер применения криптографических механизмов защиты информации.

Для каждой страны важно не допустить технологического отставания в средствах защиты информации в этих сферах, и необходимо вырабатывать согласованные криптографические решения. Успеха в решении этих задач можно добиться только путем объединения усилий активно работающих квалифицированных специалистов и действующей системы подготовки новых специалистов в области криптографии. В повышении квалификации криптографов большую роль играет постоянное информирование их о новых практически значимых направлениях развития криптографической науки и достигнутых в этих направлениях результатах, привлечение внимания специалистов к актуальным задачам синтеза и анализа криптографических алгоритмов и обмен мнениями по данной проблематике. Именно эти цели ставятся перед нашим мини-симпозиумом. По сравнению с другими научными форумами по криптографической тематике, в программе мини-симпозиума большее внимание и время отводятся результатам разработки и исследований конкретных криптографических алгоритмов, ориентированных на использование 
их в качестве стандартизированных решений. Вместе с тем программный комитет включил в программу доклады и обсуждение результатов исследований по развитию математического аппарата криптографии. Можно сказать, что представленные доклады являются довольно репрезентативной выборкой из всего спектра направлений отечественной криптографической науки. Выражаем надежду, что в перспективе мини-симпозиум станет традиционным и его рамки будут расширены, в том числе за счет докладов зарубежных специалистов.

В заключение этого краткого выступления позвольте выразить благодарность принимающей стороне - руководству и коллективу Нижегородского государственного университета имени Н. И. Лобачевского, членам программного комитета и руководству технического комитета по стандартизации ТК 26 «Криптографическая защита информации», а также спонсору минисимпозиума - компании «ИнфоТеКС» за большую работу по подготовке мини-симпозиума и пожелать успехов в его работе. 